\title{
Droplet-based microfluidic
} high-throughput screening of heterologous enzymes secreted by the yeast Yarrowia lipolytica

Thomas Beneyton ${ }^{1,2}$, Stéphane Thomas ${ }^{3}$, Andrew D. Griffiths ${ }^{1}$, Jean-Marc Nicaud ${ }^{3}$, Antoine Drevelle ${ }^{4}$ and Tristan Rossigno ${ }^{3^{*}}$

\begin{abstract}
Background: Droplet-based microfluidics is becoming an increasingly attractive alternative to microtiter plate techniques for enzymatic high-throughput screening (HTS), especially for exploring large diversities with lower time and cost footprint. In this case, the assayed enzyme has to be accessible to the substrate within the water-in-oil droplet by being ideally extracellular or displayed at the cell surface. However, most of the enzymes screened to date are expressed within the cytoplasm of Escherichia coli cells, which means that a lysis step must take place inside the droplets for enzyme activity to be assayed. Here, we take advantage of the excellent secretion abilities of the yeast Yarrowia lipolytica to describe a highly efficient expression system particularly suitable for the droplet-based microfluidic HTS.
\end{abstract}

Results: Five hydrolytic genes from Aspergillus niger genome were chosen and the corresponding five Yarrowia lipolytica producing strains were constructed. Each enzyme (endo- $\beta$-1,4-xylanase B and $C ; 1,4-\beta$-cellobiohydrolase $A$; endoglucanase $A$; aspartic protease) was successfully overexpressed and secreted in an active form in the crude supernatant. A droplet-based microfluidic HTS system was developed to (a) encapsulate single yeast cells; (b) grow yeast in droplets; (c) inject the relevant enzymatic substrate; (d) incubate droplets on chip; (e) detect enzymatic activity; and (f) sort droplets based on enzymatic activity. Combining this integrated microfluidic platform with gene expression in Y. lipolytica results in remarkably low variability in the enzymatic activity at the single cell level within a given monoclonal population $(<5 \%)$. Xylanase, cellobiohydrolase and protease activities were successfully assayed using this system. We then used the system to screen for thermostable variants of endo- $\beta$-1,4-xylanase $C$ in error-prone PCR libraries. Variants displaying higher thermostable xylanase activities compared to the wild-type were isolated (up to 4.7-fold improvement).

Conclusions: Yarrowia lipolytica was used to express fungal genes encoding hydrolytic enzymes of interest. We developed a successful droplet-based microfluidic platform for the high-throughput screening $\left(10^{5} \mathrm{strains} / \mathrm{h}\right)$ of $Y$. lipolytica based on enzyme secretion and activity. This approach provides highly efficient tools for the HTS of recombinant enzymatic activities. This should be extremely useful for discovering new biocatalysts via directed evolution or protein engineering approaches and should lead to major advances in microbial cell factory development.

Keywords: High-throughput enzymatic screening, Droplet-based microfluidics, Heterologous expression, Yarrowia lipolytica, Recombinant fungal protein

\footnotetext{
*Correspondence: tristan.rossignol@inra.fr

${ }^{3}$ Micalis Institute, INRA, AgroParisTech, Université Paris-Saclay,

78352 Jouy-en-Josas, France

Full list of author information is available at the end of the article
} 


\section{Background}

The lack of rapid and generalized high-throughput screening (HTS) systems has proven to be a major bottleneck when it comes to creating biocatalysts via directed evolution and protein engineering approaches. Currently, the most flexible and widely used HTS methods involve isolating monoclonal populations in the wells of microtiter plates. These techniques require a significant investment in terms of money, time, and space, which severely limits the number of enzymes that can be screened and, consequently, the discovery of better biocatalysts. Droplet-based microfluidics has recently emerged as an attractive alternative to conventional HTS techniques because it has significantly higher throughput and significantly lower assay volumes [1]. In this approach, cells are compartmentalized in water-in-oil (w/o) picoliter droplets that can be individually manipulated at $\mathrm{kHz}$ frequencies (e.g., created, fused, injected, incubated, or sorted based on fluorescence) [2-4]. Typically, single bacteria or yeast are compartmentalized in $10 \mathrm{pl}$ droplets allowing the screening of libraries with a 1.000 fold-increase in speed and 1-million-fold reduction in volume compared to robotic microtiter plate-based systems [5].

Most of the time, in droplet-based microfluidic systems, enzymatic activities are detected using fluorogenic substrates especially adapted to the droplet format. In particular, the fluorescent probe product should not be transported from one compartment to another one over the time scale of the assay [6,7], and the substrate should be accessible to the expressed enzymes within the w/o droplet. Consequently, the expression system must be carefully chosen and, ideally, should involve enzymes that are expressed extracellularly or at the cell surface. To date, most of the protein libraries screened have relied on cytoplasmic or periplasmic expression in Escherichia coli, which implies that both the substrate and the product travel through the cell membrane $[8,9]$ or that an additional lysis step is needed to perform the enzymatic assay [10-12]. While horseradish peroxidase libraries were screened displayed at the surface of Saccharomyces cerevisiae cells [5], none extracellular recombinant expression systems were described up to now in combination with droplet-based microfluidics.

Yeasts have the advantage of being able to perform eukaryotic post-translational processing (e.g., glycosylation, folding, sequence cleavage, etc.) and can therefore produce and secrete heterologous eukaryotic proteins in their active form. Expression and secretion of heterologous proteins have been widely studied in yeast, for which several expression systems have been commercialized. In particular, the nonconventional yeast Yarrowia lipolytica, has been used as a model organism for protein secretion [13-15], as it has a natural predisposition for protein secretion [16]. It is potentially better at producing heterologous proteins than are many other commonly used yeast [17], including Pichia pastoris, or even E. coli the most commonly exploited heterologous protein biofactory $[18,19]$. Y. lipolytica presents several major advantages as a model: its genome has been fully sequenced and annotated [20]; it is a species for which numerous genetic tools $[16,21]$ and high-throughput cloning methods [22] are available; and an ever increasing number of its promoters and secretion signal sequences have been studied, described, and evaluated [15, 23, 24].

Moreover, there are many examples of successful heterologous protein expression using Y. lipolytica [25]. Because its genetic manipulation is easy to perform and its high protein yields can easily be scaled up, $Y$. lipolytica has become a cell factory of choice for producing heterologous proteins. It would thus be highly beneficial to develop a droplet-based microfluidic HTS system that uses Y. lipolytica because it would allow for the more efficient screening of enzyme libraries and undoubtedly advance the development of microbial cell factories in major ways.

One important aspect of enzyme production requirement today is the production of cellulolytic enzymes for the conversion of the lignocellulosic biomasses into fuels and chemicals. Cellulases are multienzyme complexes (endoglucanases, cellobiohydrolases and glucosidase) that catalyze the hydrolysis of $\beta-1-4$ linkages in cellulose, while xylanases cleave internal $\beta-1,4$ linkages of the xylan backbone. Nowadays, commercially available cellulases are produced by filamentous fungi of the genera Trichoderma and Aspergillus [26, 27]. However, improvement of catalytic efficiency, thermal stability or end-product inhibition resistance will have a great potential for sustainable biorefinery process for biomass conversion [26]. Proteases, which are used to make detergent, leather, pharmaceuticals, and food, account for more than a half of the worldwide enzyme sales and therefore represent another major industrial and commercial interest [28]. Fungal proteases are less $\mathrm{pH}$ sensitive and have broader substrate specificity than do bacterial equivalents. However, they exhibit lower reaction rates and heat tolerance [28]. Addressing these weaknesses should help enhance their commercial potential.

In this study, we took advantage of $Y$. lipolytica's excellent secretion abilities to build extracellular expression systems for droplet-based microfluidic enzymatic screening applications. Five strains were constructed to produce five industrially relevant Aspergillus niger hydrolytic enzymes (two xylanases, one cellobiohydrolase, one endoglucanase and one aspartic protease); the enzymes were overexpressed and secreted in an active form. We developed a droplet-based microfluidic HTS system to encapsulate, cultivate, assay and sort yeast strains based 
on encoded enzymatic activities $\left(10^{5}\right.$ strains $\left./ \mathrm{h}\right)$. The activity levels of the xylanases, cellobiohydrolase, and protease were successfully detected in droplets with a remarkably low variability within monoclonal populations. Combining droplet-based microfluidic technology with the $Y$. lipolytica expression system provides a highly efficient and reliable platform for the high-throughput screening of recombinant enzyme activities.

\section{Results and discussion}

\section{Expression of fungal genes in Yarrowia lipolytica}

Five genes from Aspergillus niger (CBS513.88 strain [29]) encoding industrially relevant hydrolytic enzymes were used: $x \ln b$ (endo- $\beta-1,4$-xylanase B), $x \ln c$ (endo- $\beta-1,4$ xylanase $C)$, cbha (1,4- $\beta$-cellobiohydrolase A), egla (endoglucanase A), and pep1 (aspartic protease). The five genes were codon optimized and overexpressed in Y. lipolytica strain JMY2566 (see "Methods" section). This strain possesses a zeta docking platform that favors integration at that specific locus $[22,30]$, which allows for the efficient comparison of enzymatic activity among strains. The five resulting producing strains-JMY4346 $(x \ln b)$, JMY4510 $(x \operatorname{lnc})$ ), JMY4469 (ccbha), JMY4343 (egla) and JMY4407 (pep1)-were cultivated in $20 \mathrm{ml}$ of YNB glucose medium for $24 \mathrm{~h}$ and the corresponding supernatants were profiled using SDS-PAGE (Fig. 1). Each of the target enzymes was successfully overproduced and secreted as a major protein in the crude supernatant. All the enzymes demonstrated high expression levels without requiring any extensive optimization of growth conditions.

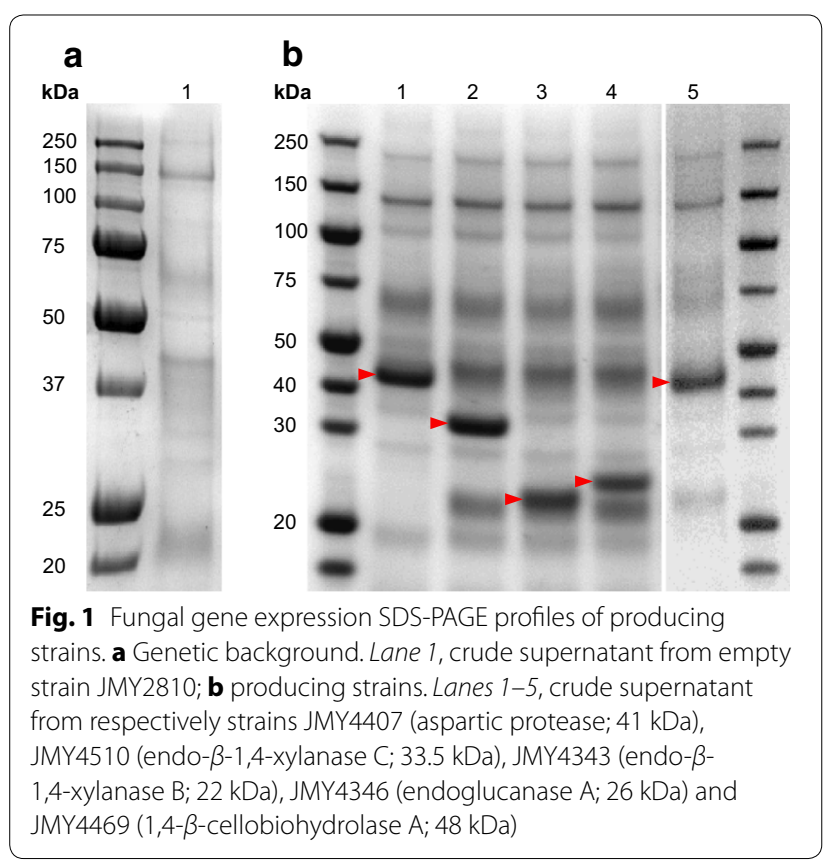

\section{Enzymatic activity of the secreted proteins}

To determine if the encoded proteins were produced in an active form, the xylanase, cellulase or protease activity was assayed in crude supernatants using fluorogenic substrates (Fig. 2). The xylanase and cellulase substrates were synthesized as previously described in [31], using a sulfonated 7-hydroxycoumarin scaffold

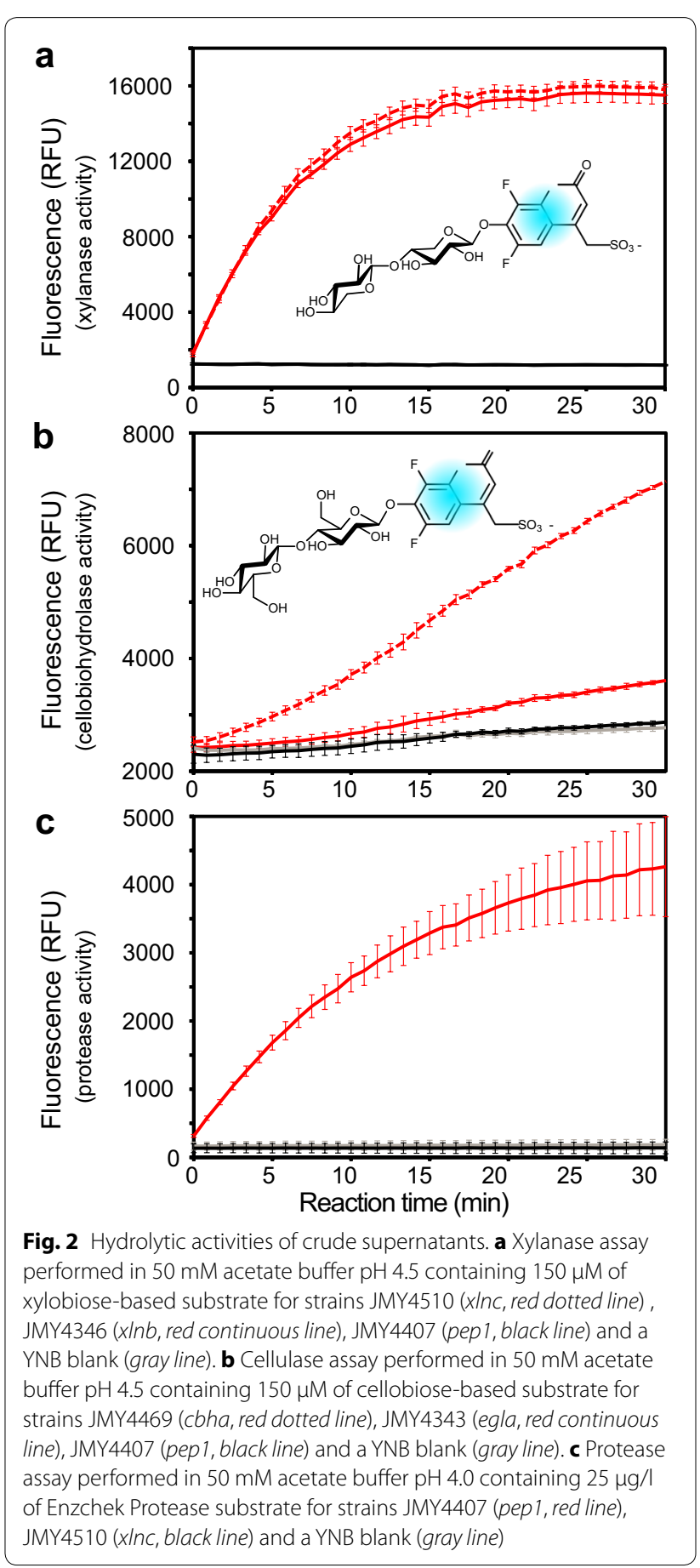


linked to a saccharide recognition unit. Xylanase activity was detected by monitoring the hydrolysis of a xylobiose-based coumarin ( $\beta$-D-xylobioside-6,8-difluoro7-hydroxycoumarin-4-methansulfonate, inset Fig. 2a) while cellulase (i.e., cellobiohydrolase) activity was detected by monitoring the hydrolysis of a cellobiose-based coumarin ( $\beta$-D-cellobioside-6,8-difluoro-7hydroxycoumarin-4-methansulfonate, inset Fig. 2b). The protease substrate is commercially available and consists of a casein scaffold labeled with quenched green-fluorescent BODIPY ${ }^{\circledR} \mathrm{FL}$ fluorophores. Protease-catalyzed hydrolysis releases the fluorophores, revealing enzyme activity. All encoded proteins were found to be active after secretion.

The JMY4346 $(x \ln b)$ and JMY4510 $(x \ln c)$ strains exhibited similar levels of endo- $\beta-1,4$-xylanase activity, corresponding to endo- $\beta-1,4-x y l a n a s e ~ B$ and endo$\beta$-1,4-xylanase C, respectively (Fig. 2a). Strain JMY4469 (cbha) displayed cellobiohydrolase activity corresponding to 1,4- $\beta$-cellobiohydrolase A (Fig. 2b). While the cellulase substrate was designed to reveal cellobiohydrolase activity, JMY4343 (egla) displayed a low activity with this substrate, seemingly due to the endocellulase activity of endoglucanase A (Fig. 2b). Lastly, strain JMY4407 (pep1) showed protease activity corresponding to aspartic protease (Fig. 2c). These results indicate that each of the five fungal hydrolytic genes was successfully overexpressed and that the corresponding recombinant enzymes were secreted in an active form.

\section{Droplet-based microfluidic HTS platform}

A droplet-based microfluidic system was developed for the enzymatic screening of recombinant proteins secreted by Y. lipolytica (Fig. 3). The platform was composed of two distinct microfluidic devices: a dropmaker and an integrated screening device. The dropmaker encapsulated single yeast cells in 20-pl droplets (Additional files 1,2 and 3 ). The cells were grown in the droplets off-chip for $16 \mathrm{~h}$ at $28{ }^{\circ} \mathrm{C}$. The droplets were then loaded in an integrated screening device (Additional files 4 and 5) to: (1) picoinject [32] the fluorogenic substrate (Additional file 6), (2) incubate the droplets on-chip as the enzymatic reaction took place (Additional file 7) and (3) analyze the fluorescence (i.e., enzymatic activity) of each droplets, which could then be sorted based on fluorescence [33].

\section{Encapsulation and growth of $Y$. lipolytica in 20 pl droplets}

Droplet-based microfluidic approaches have previously been used with S. cerevisiae [5, 34-37] but never with $Y$. lipolytica. The encapsulation procedure had to be optimized to achieve reliable single cell encapsulation. First of all, microfluidic channels are usually treated to be both hydrophobic and fluorophilic to have proper surface channel wettability for droplets formation. However, $Y$. lipolytica displays an affinity for hydrophobic substrates [38] and tended to adhere to and aggregate on channel walls when flowed in the dropmaker device. To prevent adhesion, cell suspensions were supplemented with $0.1 \%$ TWEEN $^{\circledR} 20$ non-ionic detergent. In addition, tubing with a small inner diameter $(100 \mu \mathrm{m})$ was used to increase shear stress and prevent the formation of cell aggregates prior to encapsulation. The cell suspensions were also continuously stirred during the encapsulation process to prevent cell sedimentation and variation in local cell density. Following these modifications, single Y. lipolytica cells were successfully encapsulated in $20 \mathrm{pl}$ droplets. Droplets were produced at a rate of 2500 to 3000 per second via hydrodynamic flow focusing [39] of a cell suspension with a fluorinated oil phase containing $2.5 \% \mathrm{w} / \mathrm{w}$ KryJeffD $_{900}$ fluorosurfactant [40]. The number of yeast cells per droplet followed a Poisson distribution [41] and was controlled by adjusting the initial density of the cell suspensions to give an average number of cells per droplets, $\lambda$, of 0.03-0.1 (Additional file 8). Droplets were collected off chip in a glass vial and incubated for $16 \mathrm{~h}$ at $28{ }^{\circ} \mathrm{C}$ to allow cell growth and enzyme secretion. Based on image analysis, the droplets contained dozens of cells after incubation, showing that Y. lipolytica was able to replicate in the droplets.

\section{Detection of enzymatic activities in droplets}

In the first set of experiments, the two xylanase strains JMY4346 $(x \ln b)$ and JMY4510 $(x \ln c)$ were assayed. Two strain-specific emulsions were produced sequentially with a $\lambda$ equal to 0.03 . The strains were encapsulated in growth medium containing strain-specific concentrations of sulforhodamine $\mathrm{B}$ red fluorophore to optically encode droplets (10 and $50 \mu \mathrm{M}$ for JMY4510 $[x \ln c]$ and JMY4346 $[x \ln b]$, respectively). The binary emulsion was collected in a glass vial, strains were grown for $16 \mathrm{~h}$ at $28{ }^{\circ} \mathrm{C}$, and the droplets were then loaded into the integrated screening device. The xylobiose-based coumarin substrate was picoinjected into every droplet, and fluorescence was measured immediately after injection $\left(\mathrm{t}_{0}\right.$, Fig.4 a) and after 10 min of on-chip incubation ( $\mathrm{t}_{\text {outlet }}$, Fig.4 b). As expected, both strains displayed xylanase activity. For JMY4346 $(x \ln b)$ strain, a positive droplet population showing xylanase activity (2.7\% of the droplets [theoretically $3 \%$ if $\lambda=0.03$ ]; RFU: $18.4 \pm 3.1 \%$ ) clearly demarcated from the empty droplet main population (RFU: $1 \pm 5.9 \%$ ). In the same way, for JMY4510 $(x \ln c)$ strain, a positive population (2.4\% of the droplets; RFU: $16.4 \pm 3 \%$ ) was well separated from the empty droplet population (RFU: $1 \pm 7.1 \%$ ). Both strains showed remarkably low variability in their signal distributions 


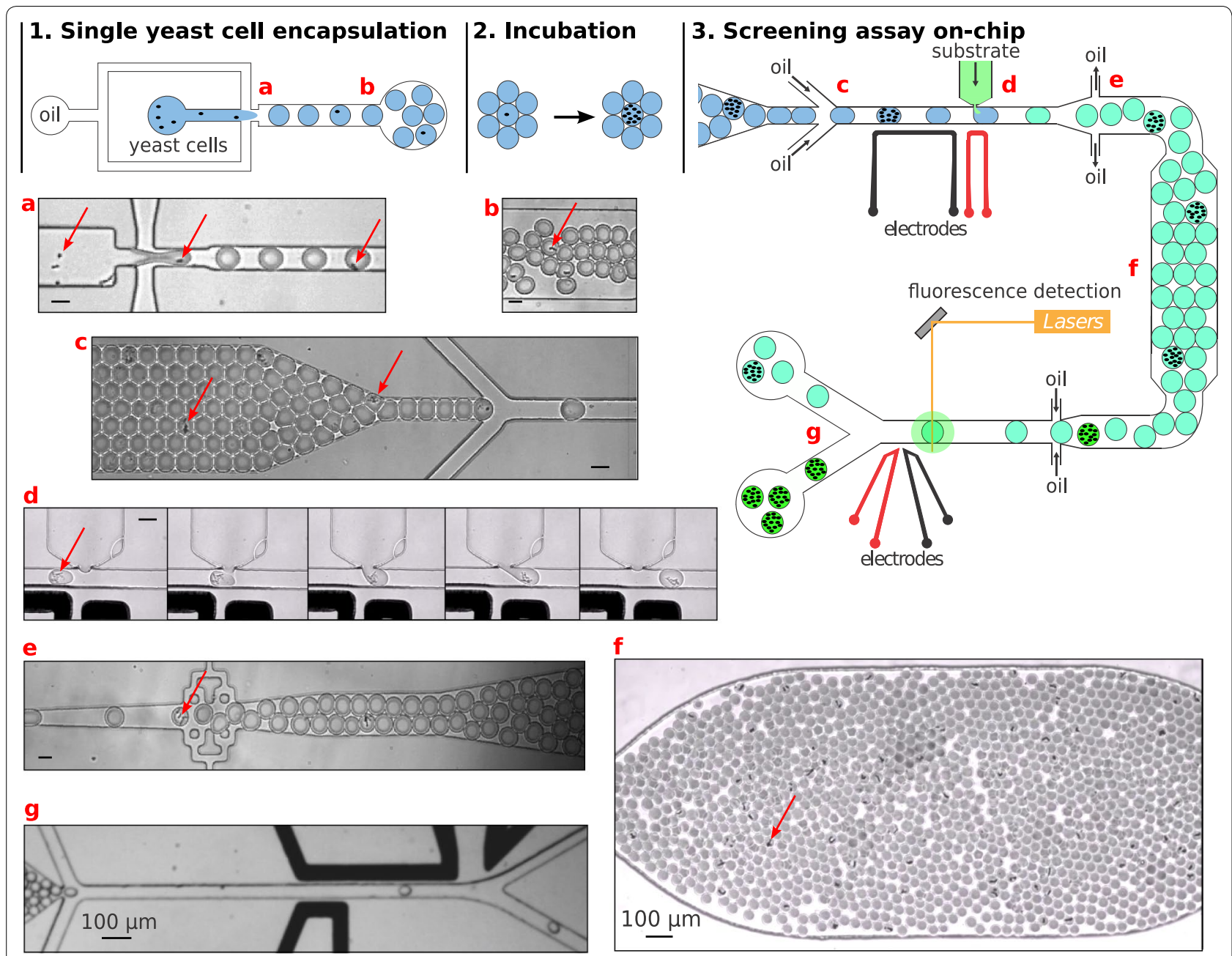

Fig. 3 Droplet-based microfluidic screening platform. 1. Single cell encapsulation: yeast cells were encapsulated in 20 pl droplets at 1200 droplets/s by flow-focusing of a cell suspension with two streams of Novec7500 oil containing 2.5\% (w/w) KryJeffD surfactant. Droplets were collected offchip in a glass vial. 2. Cell growth and enzyme secretion: droplets were incubated for $16 \mathrm{~h}$ at $28^{\circ} \mathrm{C}$. 3. Enzymatic screening: droplets were loaded

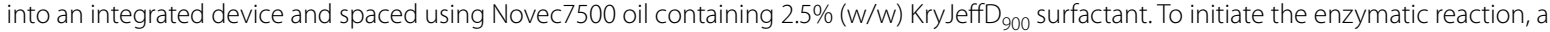
fluorogenic substrate was picoinjected in each droplet at a rate of 300 droplets $/ \mathrm{s}$ by applying an AC field $\left(20 \mathrm{kHz}, 200 \mathrm{~V}_{\text {pp }}\right.$ ). Droplets were incubated on-chip along a delay line and spaced with Novec7500 oil for fluorescence detection (i.e. enzymatic activity). Droplets could be sorted based on fluorescence at 300 droplets/s by applying AC field pulses ( $30 \mathrm{kHz} ; 1200 \mathrm{~V}_{p p} ; 0.3-0.6 \mathrm{~ms}$ ). a-f Microscopic images of the different steps of the microfluidic system. The red arrows indicate encapsulated Y. lipolytica cells. Unless specified, scale bars are $30 \mu \mathrm{m}$

(coefficient of variation $[\mathrm{CV}]$ of $3 \%$ ). This narrow phenotypic distribution at the single cell level within a monoclonal population is highly desirable for enzymatic screening applications and is due to a combination of two factors. First, the expression system developed in Y. lipolytica under a strong constitutive promoter is characterized by low variability in expression levels [42]. Second, the integrated screening device allows for a high degree of control. The injection of the substrate to initiate the enzymatic reaction and the on-chip incubation along the delay line insure a precise control of the incubation time in each droplet. More specifically, the delay line structure design, made of constrictions and expansions, ensured that average droplet residence time, and hence incubation time, displayed little variance [43].

In a second set of experiments, strains JMY4346 $(x \ln b)$, JMY4469 (cbha), and JMY4407 (pep1) were assayed for xylanase, cellobiohydrolase, and protease activity, respectively. Three strain-specific emulsions were produced sequentially with a $\lambda$ equal to $0.04,0.08$ and 0.03 for JMY4346 $(x \ln b)$, JMY4469 (cbha), and JMY4407 (pep1), respectively. The strains were encapsulated in growth medium containing strain-specific concentrations of sulforhodamine B red fluorophore to optically 

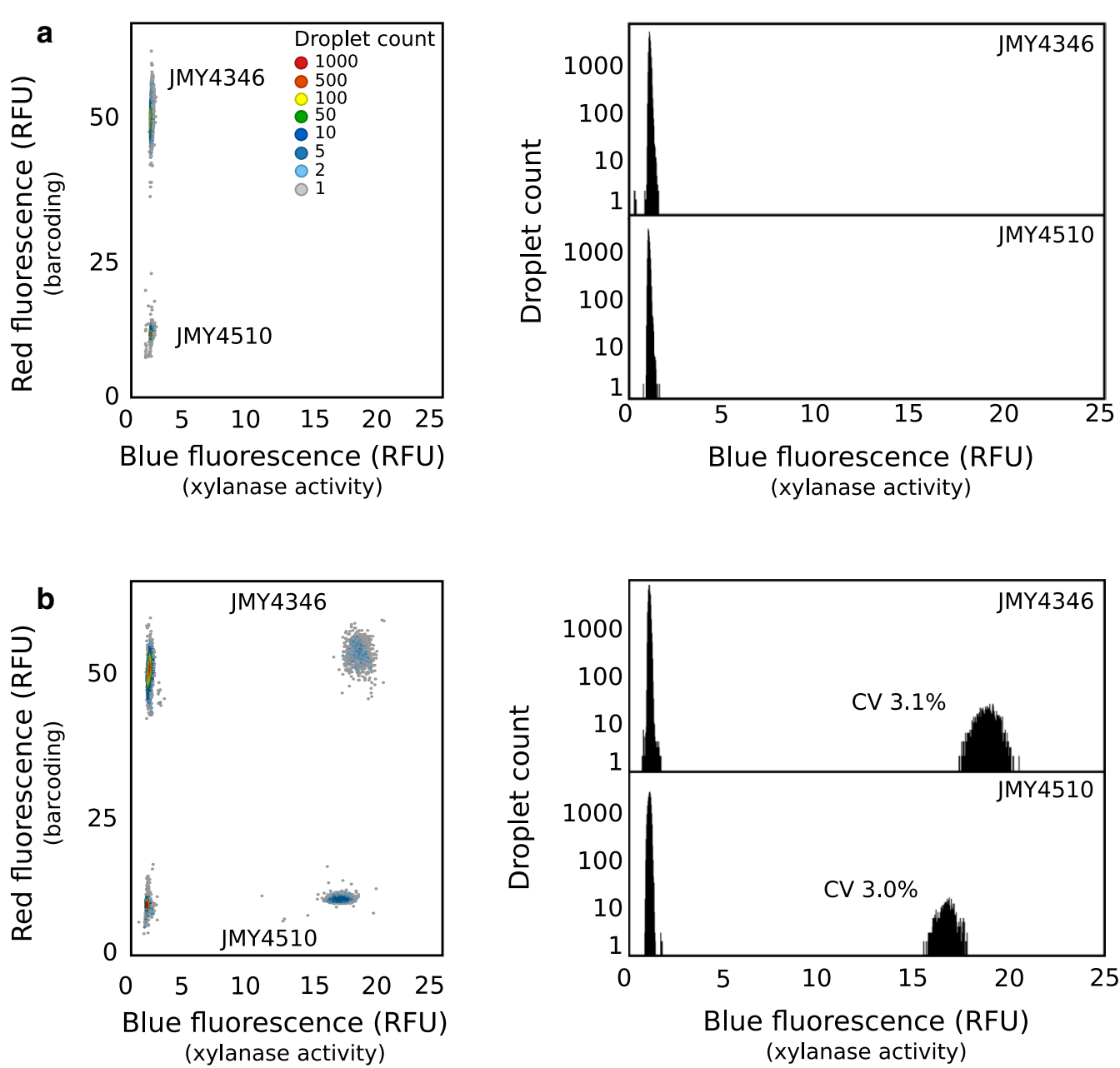

Fig. 4 JMY4346 ( $x / n b)$ and JMY4510 ( $x / n c)$ strains activity in droplets 2D histograms showing the blue fluorescence (xylanase activity) and the red fluorescence (barcoding) of a binary 20 pl droplets emulsion containing JMY4346 (x/nb) and JMY4510 (x/nc) strains analyzed in the integrated screening device just after injection of the xylanase substrate (a) and after on-chip incubation (b). On the right are displayed the 1D histograms showing the number of droplets observed as a function of the xylanase activity (blue fluorescence) corresponding to each droplet population (JMY4510 (xInc) and JMY4346 (xInb) strains)

encode droplets $(10,50$ and $100 \mu \mathrm{M}$ for JMY4346 $[x \ln b]$, JMY4407 [pep1], and JMY4469 [cbha], respectively). Following off-chip incubation, the droplets were loaded into the integrated screening device and were picoinjected with either the xylobiose-based coumarin substrate (Fig.5a), the cellobiose-based coumarin substrate (Fig.5b), or the protease substrate (Fig.5c). Each strain showed hydrolytic activity against the respective substrate with comparable narrow signal distribution, while no activity was detected for the other strains.

These results demonstrate that our droplet-based microfluidic HTS system is an efficient and reliable method for detecting endoxylanase, cellobiohydrolase, and protease activity. The low variability obtained within monoclonal populations makes this approach very useful for screening enzyme libraries in the context of protein engineering or directed evolution.

\section{Screening for thermostable mutants of the endo- $\beta$-1,4-xylanase $C$}

Improving the thermostability of the enzymatic cocktail composed of endo- $\beta-1,4$-xylanase $B$ and $C$ would be of particular interest from a biotechnological perspective in the field of animal feed. The thermostability of both xylanases against a heat shock of $90{ }^{\circ} \mathrm{C}$ for $30 \mathrm{~s}$ was investigated (Fig.6a). Crude supernatant from strains JMY4346 $(x \ln b)$ and JMY4510 $(x \ln c)$ were assayed in bulk with the xylanase substrate before and after the heat shock. 

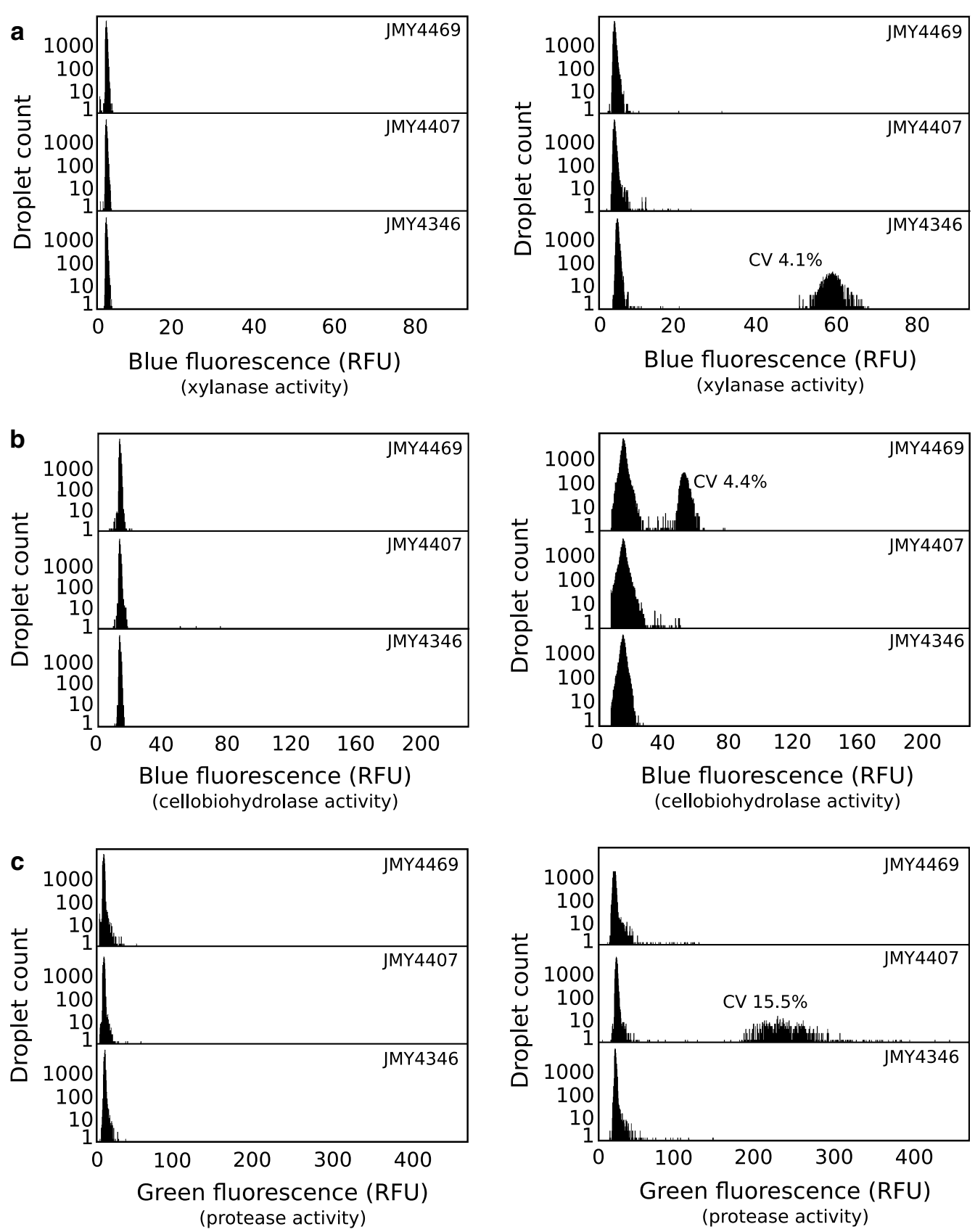

Fig. 5 JMY4346 (x/nb), JMY4469 (cbha) and JMY4407 ( pep 1) strains activity in droplets 1D histograms showing the number of droplets observed as a function of the enzymatic activity (blue or green fluorescence) for a ternary emulsion containing JMY4346 (xInb), JMY4469 (cbha) and JMY4407 (pep1) strains. The emulsion was analyzed in the integrated screening device just after injection of the relevant enzymatic substrate (left) and after on-chip incubation (right) with the xylanase substrate (a), the cellulase substrate (b) and the protease substrate (c)

Endo- $\beta-1,4$-xylanase $C$ was found to be less thermostable than endo- $\beta$-1,4-xylanase $B$ with residual activities of 3.7 and $71.7 \%$, respectively.

We therefore focused on improving endo- $\beta-1,4-$ xylanase $C$ thermostability and set up a screen for thermostable variants as proof of concept of our droplet-based microfluidic HTS system. Libraries were generated from $x \ln c$ gene using error-prone PCR. To evaluate how mutation frequency affects a library phenotypic distribution, we constructed two small libraries with different mutation frequencies: library A had a low mutation frequency (2 per $\mathrm{kb}$ ) and library B had a 


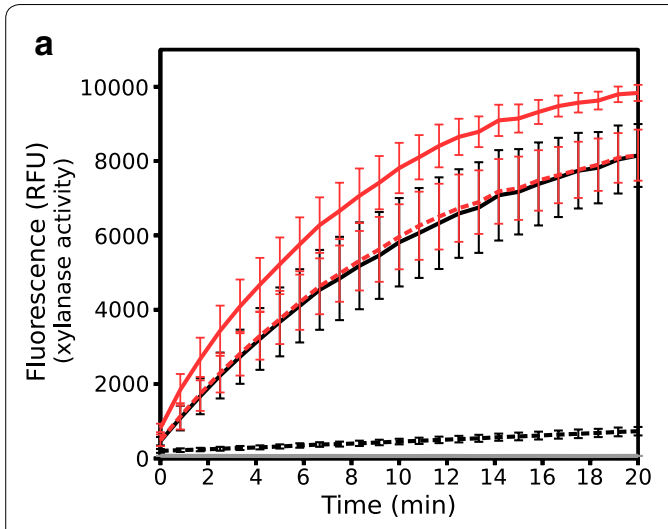

C

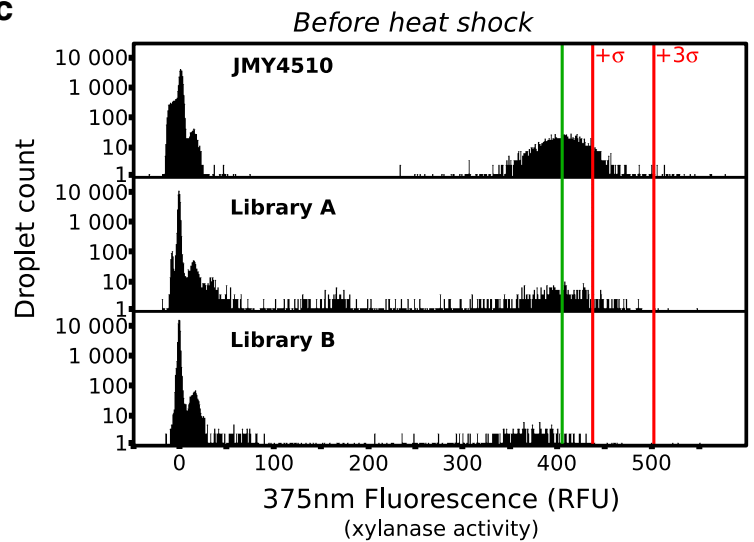

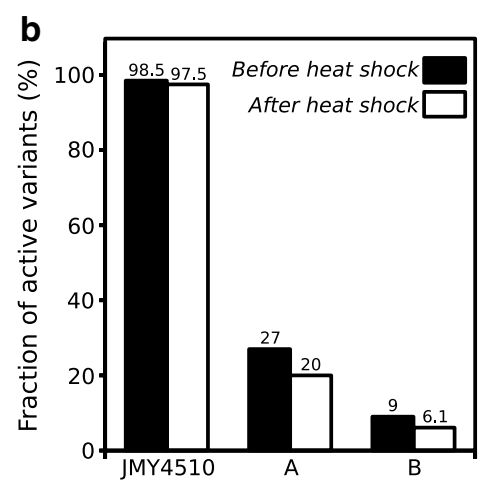
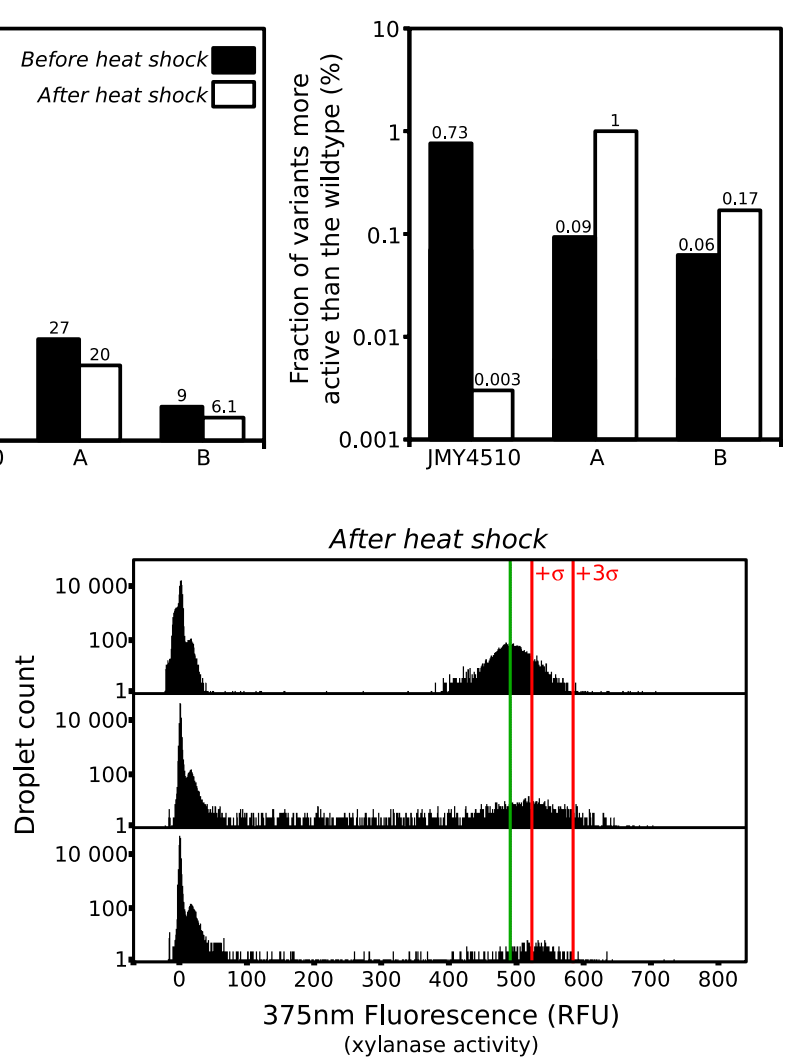

Fig. 6 Screening for thermostable variants of endo- $\beta-1,4-x y$ lanase $C$. a Thermostability of endo- $\beta-1,4-x y l a n a s e ~ B$ and $C$. Xylanase activity of the crude supernatant for the strains JMY4510 ( $x / n c$; black line) and JMY4346 ( $x \ln b$; red line) before (continuous line) and after (dotted line) a heat shock $\left(90^{\circ} \mathrm{C}, 30\right.$ s). The negative control (i.e., growth medium) is shown in gray. Error bars correspond to \pm 1 standard deviation $(N=3)$. b Microfluidics library analysis. The two libraries A and B and the parental strain (JMY4510 (x/nc)) were analyzed using the integrated microfluidic screening device. The histograms show the general percentage of variants displaying activity (left) and the proportion of variants with activity levels greater than of the parental strain (right) for the wild-type and each library before (black) and after (white) heat shock $\left(90^{\circ} \mathrm{C}, 30 \mathrm{~s}\right)$. c $1 \mathrm{D}$ histograms showing the number of droplets observed as a function of the xylanase activity before and after heat shock for the wild-type, library A and library B. The mean signal for the wild-type is indicated with a green line, and values $\sigma$ and $>3 \sigma$ are to the right of the red lines. Strains were considered to be positives when displaying a xylanase activity higher than (mean wild-type activity $+3 \sigma$ )

medium mutation frequency ( $>4$ per kb). Gene libraries were transformed in Y. lipolytica, yielding 800 clones for library A and 600 clones for library B. Using the dropletbased microfluidic HTS system described above, both libraries were analyzed before and after a heat shock of $90{ }^{\circ} \mathrm{C}$ for $30 \mathrm{~s}$ (Fig.6b, c; Additional file 9). Before exposure to heat shock, $27 \%$ of the clones (216 clones) in library A and 9\% of the clones (54 clones) in library B displayed xylanase activity. None of these clones were found to have greater activity than wild-type xylanase ( $>$ [mean wild-type activity $+3 \sigma]$ ). Those library phenotypic distributions were associated with mutation frequency: the higher mutation rate led to a lower number of active clones. After exposure to heat shock, $1 \%$ of the clones ( 8 clones) in library A were found to have higher activities than the wild-type xylanase ( $>$ [mean wild-type activity
$+3 \sigma]$ ), while this percentage was $0.17 \%$ (1 clone) for library B. Therefore, our droplet-based microfluidic HTS approach revealed that 8 and 1 potential thermostable variants could be found in library A and B respectively.

To evaluate the sensitivity of our droplet-based microfluidic HTS system as compared to more classical, lowerthroughput microtiter plate methods, 480 clones were isolated from library A and placed in 96-well plates. Each was individually screened for xylanase thermostable activity. As above, prior to the heat shock, none of the clones were found to have higher levels of activity than wild-type xylanase ( $>$ [mean wild-type activity + $3 \sigma]$; data not shown). Following the heat shock, six clones demonstrated activity greater than that in the wild-type ( $>$ [mean wild-type activity $+3 \sigma]$ ), which corresponded to $1.25 \%$ of the library. These results are very similar to 
those obtained using the droplet-based microfluidic HTS approach. The six mutants with thermostable xylanase were individually grown in test tubes and enzyme activity levels in the supernatants were evaluated in duplicate before and after a heat shock (Additional file 10). All the mutants had an absolute xylanase activity level higher than that of the wild-type after a heat shock. Four of the six clones had more than $30 \%$ residual activity; the wildtype had only $5 \%$. The sequencing of the mutated gene in the six clones reveals that they contain from 1 to 6 point mutations (average of 2.5) at the amino acid level (Additional file 11). Mutations are located all along the protein, with a higher density at the $\mathrm{N}$-terminus (Additional file 11). Thus, the thermoresistance observed for these clones is likely to be a consequence of these mutations.

\section{Conclusion}

These results show that using a droplet-based microfluidic HTS approach with the Y. lipolytica expression system allowed for a rapid, efficient, and reliable kinetic analysis of recombinant enzymes at the single cell level. This study focused on the expression of fungal genes encoding hydrolytic enzymes of biotechnological interest, but the technique could be extended to any gene encoding for an enzymatic activity that could be detected using a fluorescent assay compatible with droplet-based microfluidics. Another application will be the screening of strains having altered metabolisms using fluorescent reporter systems. We have developed a precise, highthroughput and low-cost screening technique that can be used to compare and isolate improved enzymes within libraries. This will undoubtedly help to speed up the discovery of new enzymes via directed evolution or protein engineering strategies.

\section{Methods}

\section{Strains and plasmids}

The five fungal heterologous genes from $A$. niger strain CBS 513.88- $x \ln b$ (endo- $\beta$-1,4-xylanase B), $x \ln c$ (endo$\beta$-1,4-xylanase C), cbha (1,4- $\beta$-cellobiohydrolase A), egla (endoglucanase A), and pep1 (aspartic protease)-were synthesized with codon optimization by GenScript (Piscataway, NJ, USA) and in accordance with the codon usage in Y. lipolytica. Codon optimized genes were cloned into a JMP62-type vector $[13,44]$ under the control of the strong and constitutive pTEF promoter [17]. The vectors used in this study are listed in Additional file 12. Expression vectors were digested with the restriction enzyme NotI (New England Biolabs, Evry, France) to release the expression cassettes. The gel-purified expression cassettes were then used to transform $Y$. lipolytica strain JMY2566 [22] using the lithium acetate method [45], giving rise to strains JMY4346 $(x \ln b)$, JMY4510 $(x \ln c)$, JMY4469 (cbha), JMY4343 (egla), and JMY4407 (pep1). Transformants were selected on YNB plates. Genomic DNA from the positive transformants was prepared as described elsewhere [46], and integration of the overexpression cassette at the specific zeta locus was confirmed by PCR using gene-specific primers (Additional file 13) and a primer located in the zeta locus (5'-TCTTCTGC CTCCAGGAAGTC-3'). DNA fragments were recovered from agarose gels using a QIAquick Gel Extraction Kit (Qiagen, Hikden, Germany). The QIAprep Spin Miniprep Kit (Qiagen, Hilden, Germany) was used for plasmid purification. All the reactions were performed in accordance with the manufacturer's instructions.

\section{Growth conditions}

Escherichia coli strains were grown according to standard protocols [47] in Luria-Bertani broth medium containing $50 \mu \mathrm{g} / \mathrm{ml}$ kanamycin. For the yeast inoculum, rich YPD medium containing $1 \%(\mathrm{w} / \mathrm{v})$ yeast extract, $1 \%(\mathrm{w} / \mathrm{v})$ peptone, and $2 \%(\mathrm{w} / \mathrm{v})$ glucose was used. Transformants were selected on minimal YNB medium, composed of $0.17 \%(\mathrm{w} / \mathrm{v})$ yeast nitrogen base (without amino acids and ammonium sulfate; BD Difco), $0.5 \%(\mathrm{w} / \mathrm{v}) \mathrm{NH} 4 \mathrm{Cl}$, $50 \mathrm{mM}$ phosphate buffer (pH 6.8), and $2 \%(\mathrm{w} / \mathrm{v})$ glucose. When necessary, leucine and uracil were added to a final concentration of $0.1 \mathrm{~g} \mathrm{l}$. Solid media were complemented with $1.6 \%$ agar.

Single colonies were grown for $24 \mathrm{~h}$ at $28{ }^{\circ} \mathrm{C}$ in $2 \mathrm{ml}$ of YNB glucose medium (YNB without amino acids [1.7 $\mathrm{g} / \mathrm{l}]$, yeast extract $[1.5 \mathrm{~g} / \mathrm{l}]$, glucose $[10 \mathrm{~g} / \mathrm{l}], \mathrm{NH} 4 \mathrm{Cl}[100$ $\mathrm{mM}$ ], and $\mathrm{KH}_{2} \mathrm{PO}_{4} / \mathrm{Na}_{2} \mathrm{HPO}_{4}$ buffer [ $50 \mathrm{mM}$, pH 6.8]). 20 $\mathrm{ml}$ of fresh YNB glucose medium were inoculated at an $\mathrm{OD}_{600}$ value of 0.05 . The culture was grown at $28^{\circ} \mathrm{C}$ until it reached an $\mathrm{OD}_{600}$ value of $0.4-0.6$, in the microfluidic experiments, or for $24 \mathrm{~h}$ for bulk measurements of hydrolytic activities and SDS analysis.

In the mutant library experiment, fresh YNB glucose medium was inoculated with $-80{ }^{\circ} \mathrm{C}$ glycerol stock cell suspensions with an $\mathrm{OD}_{600}$ value of 0.05 .

For growth in 96-well plates, yeasts were precultivated for $48 \mathrm{~h}$ in YPD medium in microtiter plates. $5 \mu \mathrm{l}$ of the precultures were then transferred to $120 \mu \mathrm{l}$ of fresh YNB medium and grown for $30 \mathrm{~h}$ at $28{ }^{\circ} \mathrm{C}$ on an orbital shaker at $170 \mathrm{rpm}$.

\section{SDS-PAGE analysis}

$20 \mu \mathrm{l}$ of crude supernatant were analyzed by electrophoresis on a $10 \%$ NuPAGE Bis-Tris-acetate sodium dodecyl sulfate-polyacrylamide gel (SDS-PAGE) (Thermo Fisher Scientific, Villebon-sur-Yvette, France). After migration, the gel was subject to colloidal blue staining. 


\section{Primary enzymatic activity detection on yeast transformants}

Cells were grown for $24 \mathrm{~h}$ and then removed via centrifugation $\left(6000 \mathrm{rpm}\right.$ for $20 \mathrm{~min}, 28{ }^{\circ} \mathrm{C}$ ). Xylanase, cellulase, or protease activity levels in the crude supernatants were monitored using adapted fluorescence assays in a Spectramax M5 spectrofluorometer (Molecular Devices, Wokingham, UK).

\section{Xylanase assay}

$25 \mu \mathrm{l}$ of crude supernatant was added to $25 \mu \mathrm{l}$ of a $300 \mu \mathrm{M}$ solution of $\beta$-D-xylobioside-6,8-difluoro-7hydroxycoumarin-4-methansulfonate in acetate buffer (100 mM, pH 4.5). The reaction was monitored at $25^{\circ} \mathrm{C}$ for $30 \min \left(\lambda_{\mathrm{ex}}=360 \mathrm{~nm}, \lambda_{\mathrm{em}}=460 \mathrm{~nm}\right)$.

\section{Cellobiohydrolase assay}

$25 \mu \mathrm{l}$ of crude supernatant was added to $25 \mu \mathrm{l}$ of a $300 \mu \mathrm{M}$ solution of $\beta$-D-cellobioside-6,8-difluoro-7hydroxycoumarin-4-methansulfonate in acetate bufffer (100 mM, pH 4.5). The reaction was monitored at $25^{\circ} \mathrm{C}$ for $30 \mathrm{~min}\left(\lambda_{\mathrm{ex}}=360 \mathrm{~nm}, \lambda_{\mathrm{em}}=460 \mathrm{~nm}\right)$.

\section{Protease assay}

$25 \mu \mathrm{l}$ of crude supernatant was added to $25 \mu \mathrm{l}$ of a $50 \mu \mathrm{g} /$ ml solution of Enzchek Protease Assay substrate (Thermo Fisher Scientific, Villebon-sur-Yvette, France) in acetate buffer (100 mM, pH 4.0). The reaction was monitored at $25^{\circ} \mathrm{C}$ for $30 \min \left(\lambda_{\mathrm{ex}}=480 \mathrm{~nm}, \lambda_{\mathrm{em}}=518 \mathrm{~nm}\right)$.

\section{Droplet-based microfluidics}

\section{Fabrication of microfluidic devices}

Poly-(dimethylsiloxane) (PDMS) microfluidic devices were fabricated as previously described [8] from 20 or $70 \mu \mathrm{m}$-deep molds of SU-8 2025 and SU-8 2050 negative photoresists (MicroChem Corp), respectively.

\section{Optical setup, data acquisition and control system for droplet analysis}

The optical setup used to monitor microfluidic experiments has previously been described, as well as the data acquisition and control system [31]. In addition, to allow the sorting of a particular droplet, the data acquisition card provided a signal to a model 623B high-voltage amplifier (Trek Inc.) connected to the electrodes of the microfluidic device.

\section{Surfactant synthesis}

We used aqueous droplets in Novec7500 fluorinated oil (3M) stabilized against coalescence by a triblock copolymer fluorosurfactant comprising two perfluoropolyether (PFPE) chains linked by one Jeffamine ${ }^{\circledR}$ polyetheramine chain (PEA), KryJeffD 900. KryJeffD $_{900}$ surfactant was prepared in house as previously described [40].

\section{Microfluidic chip operation}

Droplets were produced using a dropmaker device (Additional file 1) by flow-focusing the cell suspension stream with two streams of Novec7500 oil containing $2.5 \%(\mathrm{w} / \mathrm{w})$ of KryJeffD ${ }_{900}$ surfactant. The liquids were pumped into the dropmaker using standard infusion/ withdraw PHD 22/2000 syringe pumps (Harvard Apparatus Inc.). For the oil steams, a syringe (Injekt ${ }^{\circledR} ;$ BBRAUN) was connected to the dropmaker using a $0.6 \times 25 \mathrm{~mm}$ needle (Terumo) and PTFE tubing (Fisher Scientific) with an inner diameter (ID) of $0.56 \mathrm{~mm}$ and an outer diameter (OD) of $1.07 \mathrm{~mm}$. For the cell suspension stream, a glass syringe (Hamilton Gastight 1002) was connected to the dropmaker using 1/32" fluidic connections with FEP tubing (ID $102 \mu \mathrm{m}$, OD $0.79 \mathrm{~mm}$ ). The dropmaker was used to produce $20 \mathrm{pl}$ droplets $\left(\mathrm{Q}_{\text {aqueous }} 150 \mu \mathrm{l} / \mathrm{h}, \mathrm{Q}_{\text {oil }}\right.$ $400 \mu \mathrm{l} / \mathrm{h}, 2000-3000$ droplets/s). The droplets flowed off chip through PTFE tubing (IDEX) to a glass vial attached to a Peltier device, where they were incubated at $28{ }^{\circ} \mathrm{C}$ [48]. The droplets were then loaded into the integrated screening device (Additional file 4). The liquids were pressure driven into the device via PTFE tubing (ID 0.56 $\mathrm{mm}$, OD $1.07 \mathrm{~mm}$ ) using a microfluidic flow control system (MFCS $[2 \times 2$ bar inlets, $2 \times 1$ bar inlets], Fluigent). Droplets were reloaded ( $\left.\mathrm{P}_{\text {droplets }} 500-700 \mathrm{mbar}\right)$ and spaced with Novec7500 oil ( $\mathrm{P}_{\text {oil }} 500-700$ mbar). The substrate was picoinjected ( $\mathrm{P}_{\text {substrate }} 500-700$ mbar, 200-300 droplets/s) by applying an AC field $\left(20 \mathrm{kHz}, 200 \mathrm{~V}_{p p}\right)$, and the droplets were incubated on chip after oil extraction $\left(\mathrm{Q}_{\text {extrac }}-25\right.$ to $\left.-100 \mu \mathrm{l} / \mathrm{h}\right)$. The droplets were spaced after incubation $\left(\mathrm{Q}_{\text {spacing }} 200-1000 \mu \mathrm{l} / \mathrm{h}\right)$ and analyzed by the optical setup. Fluorescent droplets could be sorted at a rate of 300 droplets/s by applying a AC field pulses (30 $\left.\mathrm{kHz} ; 1200 \mathrm{~V}_{p p} ; 0.3-0.6 \mathrm{~ms}\right)$.

\section{Strain activity in droplets Yeast suspension}

$20 \mathrm{ml}$ of fresh YNB glucose medium was inoculated at an $\mathrm{OD}_{600}$ value of 0.01 . The strains were cultured at $28{ }^{\circ} \mathrm{C}$ until an $\mathrm{OD}_{600}$ value of 0.4-0.6 was reached. $15 \mathrm{ml}$ of culture were then centrifuged $\left(6000 \mathrm{rpm}, 10 \mathrm{~min}, 4{ }^{\circ} \mathrm{C}\right)$, and the resulting pellet was washed with fresh YNB glucose medium. This washing step was repeated three times, and the pellet was resuspended in $1 \mathrm{ml}$ of fresh YNB glucose containing $0.1 \%$ TWEEN $^{\circledR} 20$ and $10 \mu \mathrm{M}$ sulforhodamine $\mathrm{B}$ (barcoding dye). The $\mathrm{OD}_{600}$ was measured, and the yeast suspension was then diluted to achieve the desired number of cells per droplet volume $\left(\mathrm{an} \mathrm{OD}_{600}\right.$ of 1 corresponds to $3.4 \times 10^{7}$ cells per $\mathrm{ml}$ ). 


\section{Yeast encapsulation}

The cell suspension was encapsulated in 20-pl droplets using the dropmaker. A cylindrical PTFE magnetic stirring bar was used to avoid cell sedimentation in the syringe during the encapsulation process. The droplets were collected in a glass vial. For multiple strains emulsions, the strains were encapsulated sequentially using different level of coding dye and collected together in a single glass vial. The yeasts were cultured in the droplets at $28^{\circ} \mathrm{C}$ for $24 \mathrm{~h}$.

\section{Assays in droplets}

The droplets were loaded into the integrated screening device, and the substrate was picoinjected into every droplets (typically $5 \mathrm{pl}$ in $20 \mathrm{pl}$ droplets). To assay xylanase activity, the xylobiose-based substrate $(150 \mu \mathrm{M}$ in acetate buffer [ $50 \mathrm{mM}, \mathrm{pH} 4.5]$ ) was used. To assay cellobiohydrolase activity, the cellobiose-based substrate (150 $\mu \mathrm{M}$ in acetate buffer [ $50 \mathrm{mM}, \mathrm{pH} 4.5]$ ) was used. Fluorescence was then exited using a $375 \mathrm{~nm}$ laser. To assay protease activity, the Enzchek Protease Assay substrate $(150 \mu \mathrm{g} / \mathrm{ml}$ in acetate buffer [50 mM, pH 4.0]) was used. Fluorescence was then exited using a $488 \mathrm{~nm}$ laser. Droplet fluorescence was measured just after injection (reaction initiation, $\left.\mathrm{t}_{0}\right)$ and after on-chip incubation (10 $\mathrm{min}$ at room temperature, $\mathrm{t}_{\text {outlet }}$ ).

\section{Screening for thermoresistant xylanase \\ Construction of error prone $x$ Inc mutant libraries}

The expression cassette from plasmid JME2603 (Additional file 12) is flanked by zeta regions and is composed of a URA3 marker, the pTEF promoter, and the $x \ln c$ gene (Additional file 14). We built libraries of error-prone $x \ln c$ variants using a two-step PCR amplification according to [30]. First, the PCR fragment composed of Zeta1, the URA3 marker, and the pTEF promoter was amplified using Zetalfor (5'-GCGGCCGCTGTCGGGAACCG-3') and ep-PCRrev (5'-CCGATCCTTCGGGTGTGAGTTGACAAGGAG-3') as primers and JME2603 as a template under standard conditions (100 pmoles of each primer, $5 \mathrm{ng}$ of DNA template, $0.25 \mathrm{mM}$ dNTP, $1 \mathrm{U}$ Pyrobest [Takara], and $1 \mathrm{X}$ Pyrobest buffer in a final $50 \mu \mathrm{l}$ ), which produced a 2037-bp fragment (Additional file 14 PCR1). Then, the PCR fragment composed of $x \operatorname{lnc}$ and Zeta2 was amplified using epPCRfor (5'-CTCCTTGTCAACTCACACCCGAAGGATCGG-3') and Zeta2rev
(5'-GCGGCCGCACTGAGGGCTTTG-3') as primers and JME2603 as a template under mutagenic conditions (epPCR), which produced a 1557-bp fragment (Additional file 14; PCR2). A low-fidelity Taq DNA polymerase (NEB) was used, as per standard procedure; we also added either 1 or $2 \mu \mathrm{l}$ of a dNTP mutation mix ( $8 \mathrm{mM}$ dTTP, $8 \mathrm{mM}$ $\mathrm{dCTP}, 96 \mathrm{mM} \mathrm{MgCl}_{2}$, and $10 \mathrm{mM} \mathrm{MnCl}_{2}$ in water) to generate a low mutation rate library $\mathrm{A}$ or a medium mutation rate for library B, respectively. Primers epPCRrev and epP$\mathrm{CRfor}$ are reverse and complementary. The PCR fragments were recovered from agarose gels using a QIAquick Gel Extraction Kit (Qiagen). A fusion PCR was then performed under standard conditions using Zeta1for and Zeta2rev as primers and an equimolar proportion of both fragments as templates (Additional file 14; PCR3). The resulting PCR fragments containing the full mutated expression cassette were used to transform Y. lipolytica JMY2566 as described in the section on strain and plasmid.

\section{Library analysis in microfluidics}

The JMY4510 $(x \ln c)$ wild-type, library A, and library B were encapsulated in $20 \mathrm{pl}$ droplets as described above. After $16 \mathrm{~h}$ of incubation at $28{ }^{\circ} \mathrm{C}$, the droplets were loaded into the integrated screening device to assay xylanase activity as described above. To generate the heat shock, the droplets were run through PTFE tubing $(0.56$ $\mathrm{mm} \times 1.07 \mathrm{~mm}$ ) immersed in a $90{ }^{\circ} \mathrm{C}$ water bath. The flow rate was set such that residence time within the tubing was $30 \mathrm{~s}$. The droplets were then collected in a glass vial and reloaded into the integrated screening device to assay post-heat-shock levels of xylanase activity.

\section{Xylanase activity screening of mutant library in microtiter plate}

The microtiter plate cultures were centrifuged, and the supernatants were transferred to new microtiter plates. Xylanase activity was assayed using the EnzChek Ultra Xylanase Assay Kit (Thermo Fisher Scientific, Villebonsur-Yvette, France). Briefly, $5 \mu$ of supernatant was diluted in $45 \mu \mathrm{l}$ of buffer. $25 \mu \mathrm{l}$ of substrate $(50 \mu \mathrm{g} / \mathrm{ml})$ was added, and the resulting fluorescence was monitored (Biotek $\mathrm{Mx}$ microtiter plate reader, $\lambda_{e m}=360 \mathrm{~nm}, \lambda_{e m}=460 \mathrm{~nm}$ ) under constant agitation for $30 \mathrm{~min}$. Vmax was calculated using a five-point window. The supernantants were then exposed to a heat shock event $\left(90^{\circ} \mathrm{C}, 30 \mathrm{~s}\right)$ and placed on ice. Xylanase activity was assayed as described above. 


\section{Additional files}

Additional file 1: Figure S1. Description of the dropmaker device. Droplets were produced by flow-focusing of the aqueous stream (inlet a) with two streams of fluorinated oilcontaining surfactant (inlet b). The device was used to produce $20 \mathrm{pl}$ droplets that were collected off-chip (outlet c). The width of the microfluidic channels was $20 \mu \mathrm{m}$.

Additional file 2: Movie 1. Encapsulation of Y. lipolytica cells in $20 \mathrm{pl}$ droplets. Movie of the dropmaker device during droplets formation. A Y. lipolytica cell suspension was encapsulated in 20 pl droplets. Droplets were produced at $3000 \mathrm{~Hz}$

Additional file 3: Movie 2. Encapsulation of Y. lipolytica cells in $20 \mathrm{pl}$ droplets. Movie of the dropmaker device during droplet collection. Single Y. lipolytica cells can be seen in the 20 pl droplets.

Additional file 4: Figure S2. Description of the integrated screening device. Droplets were loaded (inlet b) and spaced by two streams of fluorinated oil containing surfactant (inlet a). The relevant enzymatic substrate (inlet c) was injected into each droplet by applying an AC field (20kHz, 200 $\left.V_{p p}\right)$. The droplet contents were then mixed and the oil was extracted to increase the packing degree of the emulsion (inlet d, panel 2). Droplets were then incubated along the delay line and again spaced with two streams of fluorinated oil (inlets e) before entering the sorting module. The fluorescence of each droplet was measured. By default, the droplets flowed in the channel with the lower hydrodynamic resistance (outlet $\mathrm{f}$ ). Droplets could be sorted based fluorescence intensity by applying AC field pulses (30 kHz; $1200 \mathrm{~V}_{p p} ; 0.3-0.6 \mathrm{~ms}$ ) and collected (outlet g).

Additional file 5: Movie 3. Loading of the droplets into the microfluidic screening device. Movie of the microfluidic screening device at the loading part. Droplets were loaded and spaced with two oil streams. Droplets containing Y. lipolytica cells that were cultivated overnight can be seen.

Additional file 6: Movie 4. Picoinjection of the fluorogenic substrate. Movie of the microfluidic screening device at the picoinjection part. The relevant fluorogenic substrate was injected in each droplet by applying an AC field $\left(20 \mathrm{kHz}, 200 \mathrm{~V}_{p p}\right)$.

Additional file 7: Movie 5. On-chip droplets incubation. Movie of the microfluidic screening device at the incubation part. The droplets were incubated on-chip along a delay line, allowing the enzymatic reaction to turnover.

Additional file 8: Figure S3. Poisson's law distribution during encapsulation process. The number of yeast cells per droplets $(k)$ after the encapsulation process is following a Poisson distribution and depends on the initial average number of cells per droplets $(\lambda)$ of the encapsulated cell suspension.

Additional file 9: Figure S4. Microfluidic library analysis. The two libraries $A$ and $B$ and the parental strain JMY4510 ( $x / n c$ ) were analyzed using the microfluidic screening device before (a) and after (b) heat shock $\left(90^{\circ} \mathrm{C}, 30\right.$ $\mathrm{sec}$. On the left, 1D histograms show the number of droplets observed as a function of the xylanase activity (blue fluorescence) for the ternary emulsion containing, from top to bottom, JMY4510 (x/nc), library A and library B. The mean signal for the wild-type is indicated with a green line, and values $>\sigma$ and $>3 \sigma$ are to the right of the red lines. Strains were considered to be positives when displaying a xylanase activity higher than (mean wild-type activity $+3 \sigma$ ). The tables on the right provide the statistics for each population, both at the droplet and the cell level.

Additional file 10: Table S1. Thermostable variants of endo- $\beta-1,4-$ xylanase $\mathrm{C}$. Xylanase activity (RFU average) before and after heat treatment $\left(90^{\circ} \mathrm{C}\right)$ and residual activity of the 6 thermoresistant clones.

Additional file 11: Figure S5. Sequence alignment. Clustal multiple sequence alignment of the endo- $\beta-1,4$-xylanase $C$ amino acid sequence and the translated sequencesof the mutated XYNC in the six clones identified as thermoresistant. Mutations are underlined in yellow.

Additional file 12: Table S2. Y. lipolytica and E. coli strains used in this study.
Additional file 13: Table S3. List of primers used to check cassette integration at the specific Zeta locus.

Additional file 14: Figure S6. Construction of $x / n c$ libraries using errorprone PCR. The construction of xInc mutant libraries was obtained by PCR amplification in two steps. First step, the PCR fragment composed of Zeta1, URA3 marker and PTEF promoter was amplified using primers Zeta1 for and epPCRrev using the JME2603 plasmid as a template (top figure) under normal PCR condition (PCR1). Then, the PCR fragment composed of $x / n c$ and Zeta2 was amplified using primers epPCR-for and Zeta2rev and the JME2603 plasmid as a template (top figure) under epPCR mutagenic conditions (PCR2). Second step, a fusion PCR was performed under standard PCR conditions using an equimolar proportion of both fragments as templates and using primers Zeta1for and Zeta2rev (PCR3).

\section{Authors' contributions}

$T B, A D, J M N$ and TR designed the experiments. TB conducted the experiments, collected the data, and analyzed the experiments. ST constructed the strains and the libraries. TR performed the microtiter-based screening of thermostable xylanase. AD, AG, JMN and TR conceived the project and supervised the experiments. TB, TR, and JMN wrote the manuscript. All authors read and approved the final manuscript.

\section{Author details}

1 Ecole Supérieure de Physique et de Chimie industrielles de la Ville de Paris (ESPCI Paris), CNRS UMR 8231, 10 rue Vauquelin, 75005 Paris, France. ${ }^{2}$ CNRS, University of Bordeaux, CRPP, UPR 8641, 115 Avenue Albert Schweitzer, 33600 Pessac, France. ${ }^{3}$ Micalis Institute, INRA, AgroParisTech, Université Paris-Saclay, 78352 Jouy-en-Josas, France. ${ }^{4}$ Ets J. Soufflet/CRIS-OSIRIS, Quai Sarrail, BP12, 10400 Nogent-sur-Seine, France.

\section{Acknowledgements}

We thank Estelle Mayot for synthesizing the xylobiose- and cellobiose-based substrates as well as the surfactant. This work was supported by Bpifrance and Ets. J. Soufflet (OSIRIS project). This work used microfluidics tools belonging to Ets. J. Soufflet and hosted by ESPCI, Paris. We would also like to thank Jessica Pearce for its language editing services.

\section{Competing interests}

The authors declare that they have no competing interests.

\section{Availability of data and materials}

Please contact corresponding author for data requests.

\section{Consent for publication}

Our manuscript does not contain any individual person's data in any form.

\section{Ethics approval and consent to participate}

Our manuscript does not report data collected from humans or animals.

Received: 22 October 2016 Accepted: 12 January 2017

Published online: 31 January 2017

\section{References}

1. Price AK, Paegel BM. Discovery in droplets. Anal Chem. 2016;88(1):339-53.

2. Seemann R, Brinkmann M, Pfohl T, Herminghaus S. Droplet based microfluidics. Rep Prog Phys. 2011;75:016601.

3. Theberge AB, Courtois F, Schaerli Y, Fischlechner M, Abell C, Hollfelder F, Huck WTS. Microdroplets in microfluidics: an evolving platform for discoveries in chemistry and biology. Angewandte Chemie International Edition. 2010;49(34):5846-68.

4. Sciambi A, Abate AR. Accurate microfluidic sorting of droplets at $30 \mathrm{kHz}$. Lab Chip. 2014;15:47-51.

5. Agresti JJ, Antipov E, Abate AR, Ahn K, Rowat AC, Baret J-C, Marquez M, Klibanov AM, Griffiths AD, Weitz DA. Ultrahigh-throughput screening 
in drop-based microfluidics for directed evolution. Proc Natl Acad Sci. 2010;107(9):4004-9.

6. Gruner P, Riechers B, Semin B, Lim J, Johnston A, Short K, Baret JC. Controlling molecular transport in minimal emulsions. Nat Commun. 2016;7.

7. Woronoff G, El Harrak A, Mayot E, Schicke O, Miller OJ, Soumillion P, Griffiths AD, Ryckelynck M. New generation of amino coumarin methyl sulfonate-based fluorogenic substrates for amidase assays in dropletbased microfluidic applications. Anal Chem. 2011;83(8):2852-7.

8. Beneyton T, Coldren F, Baret J-C, Griffiths AD, Taly V. CotA laccase: high-throughput manipulation and analysis of recombinant enzyme libraries expressed in E. coli using droplet-based microfluidics. Analyst. 2014;139:3314-23.

9. Hosokawa M, Hoshino Y, Nishikawa Y, Hirose T, Yoon DH, Mori T, Sekiguchi T, Shoji S, Takeyama H. Droplet-based microfluidics for high-throughput screening of a metagenomic library for isolation of microbial enzymes. Biosens Bioelectron. 2015;67:379-85.

10. Romero PA, Tran TM, Abate AR. Dissecting enzyme function with microfluidic-based deep mutational scanning. Proc Natl Acad Sci. 2015;112(23):7159-64.

11. Kintses B, Hein C, Mohamed MF, Fischlechner M, Courtois F, Lainé C, HolIfelder F. Picoliter cell lysate assays in microfluidic droplet compartments for directed enzyme evolution. Chem Biol. 2012;19:1001-9.

12. Colin PY, Kintses B, Gielen F, Miton CM, Fischer G, Mohamed MF, Hyvonen M, Morgavi DP, Janssen DB, Hollfelder F. Ultrahigh-throughput discovery of promiscuous enzymes by picodroplet functional metagenomics. Nat Commun. 2015;6.

13. Nicaud J-M, Madzak C, van den Broek P, Gysler C, Duboc P, Niederberger $P$, Gaillardin C. Protein expression and secretion in the yeast Yarrowia lipolytica. FEMS Yeast Res. 2002;2:371-9.

14. Nicaud JM. Yarrowia lipolytica. Yeast. 2012;29(10):409-18.

15. Madzak C. Yarrowia lipolytica: recent achievements in heterologous protein expression and pathway engineering. Appl Microbiol Biotechnol. 2015;99(11):4559-77.

16. Barth G, Gaillardin C. Physiology and genetics of the dimorphyc fungus Yarrowia lipolytica. FEMS Microbiol Rev. 1997;19:219-37.

17. Müller S, Sandal T, Kamp-Hansen P, Dalbøge H. Comparison of expression systems in the yeasts Saccharomyces cerevisiae, Hansenula polymorpha, Klyveromyces lactis, Schizosaccharomyces pombe and Yarrowia lipolytica. Cloning of two novel promoters from Yarrowia lipolytica. Yeast. 1998;14(14):1267-83.

18. Boonvitthya N, Bozonnet S, Burapatana V, O'Donohue MJ, Chulalaksananukul W. Comparison of the heterologous expression of Trichoderma reesei endoglucanase II and cellobiohydrolase II in the yeasts Pichia pastoris and Yarrowia lipolytica. Mol Biotechnol. 2013;54(2):158-69.

19. Nars G, Saurel O, Bordes F, Saves I, Remaud-Siméon M, André I, Milon A, Marty A. Production of stable isotope labelled lipase Lip2 from Yarrowia lipolytica for NMR: investigation of several expression systems. Protein Expr Purif. 2014;101:14-20.

20. Dujon B, Sherman D, Fischer G, Durrens P, Casaregola S, Lafontaine I, de Montigny J, Marck C, Neuveglise C, Talla E, Goffard N, Frangeul L, Aigle M, Anthouard V, Babour A, Barbe V, Barnay S, Blanchin S, Beckerich J-M, Beyne E, Bleykasten C, Boisrame A, Boyer J, Cattolico L, Confanioleri F, de Daruvar A, Despons L, Fabre E, Fairhead C, Ferry-Dumazet H, Groppi A, Hantraye $F$, Hennequin $C$, Jauniaux N, Joyet P, Kachouri R, Kerrest A, Koszul R, Lemaire M, Lesur I, Ma L, Muller H, Nicaud J-M, Nikolski M, Oztas S, Ozier-Kalogeropoulos O, Pellenz S, Potier S, Richard G-F, Straub M-L, Suleau A, Swennen D, Tekaia F, Wesolowski-Louvel M, Westhof E, Wirth B, Zeniou-Meyer M, Zivanovic I, Bolotin-Fukuhara M, Thierry A, Bouchier C, Caudron B, Scarpelli C, Gaillardin C, Weissenbach J, Wincker P, Souciet J-L. Genome evolution in yeasts. Nature. 2004;430(6995):35-44.

21. Fickers P, Fudalej F, Nicaud J-M, Destain J, Thonart P. Selection of new over-producing derivatives for the improvement of extracellular lipase production by the non-conventional yeast Yarrowia lipolytica. J Biotechnol. 2005;115(4):379-86.

22. Leplat C, Nicaud JM, Rossignol T. High-throughput transformation method for Yarrowia lipolytica mutant library screening. FEMS Yeast Res. 2015;15(6):fov052.

23. Madzak C, Tréton B, Blanchin-Roland S. Strong hybrid promoters and integrative expression/secretion vectors for quasi-constitutive expression of heterologous proteins in the yeast Yarrowia lipolytica. J Mol Microbiol Biotechnol. 2000;2(2):207-2016.
24. Blazeck J, Reed B, Garg R, Gerstner R, Pan A, Agarwala V, Alper HS. Generalizing a hybrid synthetic promoter approach in Yarrowia lipolytica. Appl Microbiol Biotechnol. 2013:97(7):3037-52.

25. Madzak C, Beckerich JM. Heterologous protein expression and secretion in Yarrowia lipolytica. Berlin: Springer; 2013. p. 1-76.

26. Bisaria $\mathrm{V}$, Kondo A. Bioprocessing of renewable resources to commodity bioproducts. New York: Wiley; 2014. p. 105-32.

27. Farinas CS. Developments in solid-state fermentation for the production of biomass-degrading enzymes for the bioenergy sector. Renew Sustain Energy Rev. 2015;52:179-88.

28. Rao MB, Tanksale AM, Ghatge MS, Deshpande W. Molecular and biotechnological aspects of microbial proteases. Microbiol Mol Biol Rev. 1998;62(3):597-635.

29. Pel HJ, de Winde JH, Archer DB, Dyer PS, Hofmann G, Schaap PJ, Turner G, de Vries RP, Albang R, Albermann K, Andersen MR, Bendtsen JD, Benen JAE, van den Berg M, Breestraat S, Caddick MX, Contreras R, Cornell M, Coutinho PM, Danchin EGJ, Debets AJM, Dekker P, van Dijck PWM, van Dijk A, Dijkhuizen L, Driessen AJM, D'Enfert C, Geysens S, Goosen C, Groot GSP, de Groot PWJ, Guillemette T, Henrissat B, Herweijer M, van den Hombergh JPTW, van den Hondel CAMJJ, van der Heijden RTJM, van der Kaaij RM, Klis FM, Kools HJ, Kubicek CP, van Kuyk PA, Lauber J, Lu $X$, van der Maarel MJEC, Meulenberg R, Menke H, Mortimer MA, Nielsen J, Oliver SG, Olsthoorn M, Pal k, van Peij NNME, Ram AFJ, Rinas U, Roubos JA, Sagt CMJ, Schmoll M, Sun J, Ussery D, Varga J, Vervecken W, van de Vondervoort PJJ, Wedler H, Wösten HAB, Zeng AP, van Ooyen AJJ, Visser $\mathrm{J}$, Stam H. Genome sequencing and analysis of the versatile cell factory Aspergillus niger CBS 513.88. Nat Biotechnol. 2007;25(2):221-31.

30. Bordes F, Tarquis L, Nicaud J-M, Marty A. Isolation of a thermostable variant of Lip2 lipase from Yarrowia lipolytica by directed evolution and deeper insight into the denaturation mechanisms involved. J Biotechnol. 2011;156(2):117-24

31. Najah M, Mayot E, Mahendra-Wijaya IP, Griffiths AD, Ladame S, Drevelle A. New glycosidase substrates for droplet-based microfluidic screening. Anal Chem. 2013;85:9807-14.

32. Abate AR, Hung T, Mary P, Agresti JJ, Weitz DA. High-throughput injection with microfluidics using picoinjectors. Proc Nat Acad Sci. 2010;107(45):19163-6.

33. Baret J-C, Miller OJ, Taly V, Ryckelynck M, El-Harrak A, Frenz L, Rick C, Samuels ML, Hutchison JB, Agresti JJ, Link DR, Weitz DA, Griffiths AD. Fluorescence-activated droplet sorting (FADS): efficient microfluidic cell sorting based on enzymatic activity. Lab Chip. 2009;9(13):1850-8.

34. Boitard L, Cottinet D, Kleinschmitt C, Bremond N, Baudry J, Yvert G, Bibette J. Monitoring single-cell bioenergetics via the coarsening of emulsion droplets. Proc Natl Acad Sci. 2012;109(19):7181-6.

35. Sjostrom SL, Bai Y, Huang M, Liu Z, Nielsen J, Joensson HN, Andersson Svahn $\mathrm{h}$. High-throughput screening for industrial enzyme production hosts by droplet microfluidics. Lab Chip. 2014;14:806-13.

36. Wang BL, Ghaderi A, Zhou H, Agresti JJ, Weitz DA, Fink GR, Stephanopoulos G. Microfluidic high-throughput culturing of single cells for selection based on extracellular metabolite production or consumption. Nat Biotechnol. 2014;32:473-8.

37. Huang M, Bai Y, Sjostrom SL, Hallström BM, Liu Z, Petranovic D, Uhlén $\mathrm{M}$, Joensson HN, Andersson-Svahn H, Nielsen J. Microfluidic screening and whole-genome sequencing identifies mutations associated with improved protein secretion by yeast. Proc Natl Acad Sci. 2015;112(34):4689-96.

38. Fickers $\mathrm{P}$, Benetti $\mathrm{P}-\mathrm{H}$, Waché $\mathrm{Y}$, Marty A, Mauersberger S, Smit MS, Nicaud J-M. Hydrophobic substrate utilisation by the yeast Yarrowia lipolytica, and its potential applications. FEMS Yeast Res. 2005:5(6-7):527-43.

39. Anna SL, Bontoux N, Stone HA. Formation of dispersions using flow focusing in microchannels. Appl Phys Lett. 2003;82(3):364-6.

40. Beneyton T, Wijaya IPM, Postros P, Najah M, Leblond P, Couvent A, Mayot E, Griffiths AD, Drevelle A. High-throughput screening of filamentous fungi using nanoliter-range droplet-based microfluidics. Scientific Rep. 2016:6:27223

41. Clausell-Tormos J, Lieber D, Baret J-C, El-Harrak A, Miller OJ, Frenz L, Blouwolff J, Humphry KJ, Köster S, Duan H, Holtze C, Weitz DA, Griffiths AD, Merten CA. Droplet-based microfluidic platforms for the encapsulation and ccreening of mammalian cells and multicellular organisms. Chem Biol. 2008;15(5):427-37. 
42. Cambon E, Piamtongkam R, Bordes F, Duquesne S, Laguerre S, Nicaud JM, Marty A. A new Yarrowia lipolytica expression system: an efficient tool for rapid and reliable kinetic analysis of improved enzymes. Enzyme Microbial Technol. 2010;47(3):91-6.

43. Frenz L, Blank K, Brouzes E, Griffiths AD. Reliable microfluidic on-chip incubation of droplets in delay-lines. Lab Chip. 2009;9(10):1344-8.

44. Pignède G, Wang H-J, Fudalej F, Seman M, Gaillardin C, Nicaud J-M Autocloning and amplification of LIP2 in Yarrowia lipolytica. Appl Environ Microbiol. 2000;66(8):3283-9.

45. Le Dall M-T, Nicaud J-M, Gaillardin C. Multiple-copy integration in the yeast Yarrowia lipolytica. Curr Genetics. 1994;26(1):38-44.
46. Querol A, Barrio E, Huerta T, Ramón D. Molecular monitoring of wine fermentations conducted by active dry yeast strains. Appl Environ Microbiol. 1992;58(9):2948-53.

47. Sambrook J, Russell R. Molecular cloning: a laboratory manual. New York: Cold Spring Harbor Laboratory Press; 2001.

48. Mazutis L, Araghi AF, Miller OJ, Baret J-C, Frenz L, Janoshazi A, Taly V, Miller BJ, Hutchison JB, Link D, Griffiths AD, Ryckelynck M. Droplet-based microfluidic systems for high-throughput single DNA molecule isothermal amplification and analysis. Anal Chem. 2009;81(12):4813-21.

\section{Submit your next manuscript to BioMed Central and we will help you at every step:}

- We accept pre-submission inquiries

- Our selector tool helps you to find the most relevant journal

- We provide round the clock customer support

- Convenient online submission

- Thorough peer review

- Inclusion in PubMed and all major indexing services

- Maximum visibility for your research

Submit your manuscript at www.biomedcentral com/submit 